\title{
Influence of corn silage hybrid type on lactation performance by Holstein dairy cows
}

\author{
M. S. Akins ${ }^{* 1,2}$ and R. D. Shavert \\ *School of Agriculture, University of Wisconsin-Platteville, Platteville 53818 \\ †Department of Dairy Science, University of Wisconsin, Madison 53706
}

\begin{abstract}
The primary objective of this study was to determine lactation performance by dairy cows fed nutridense (ND), dual-purpose (DP), or brown midrib (BM) corn silage hybrids at the same concentration in the diets. A secondary objective was to determine lactation performance by dairy cows fed NutriDense corn silage at a higher concentration in the diet. One hundred twenty-eight Holstein and Holstein $\times$ Jersey cows $(105$ $\pm 38 \mathrm{~d}$ in milk) were stratified by breed and parity and randomly assigned to 16 pens of 8 cows each. Pens were then randomly assigned to 1 of 4 treatments. Three treatment total mixed rations (TMR; DP40, BM40, and ND40) contained $40 \%$ of dry matter (DM) from the respective corn silage hybrid and $20 \%$ of DM from alfalfa silage. The fourth treatment TMR had ND corn silage as the sole forage at $65 \%$ of DM (ND65). A 2-wk covariate adjustment period preceded the treatment period, with all pens receiving a TMR with equal proportions of DP40, BM40, and ND40. Following the covariate period, cows were fed their assigned treatment diets for 11 wk. nutridense corn silage had greater starch and lower neutral detergent fiber (NDF) content than $\mathrm{DP}$ or $\mathrm{BM}$, resulting in ND40 having greater energy content $(73.2 \%$ of total digestible nutrients, TDN) than DP40 or BM40 (71.9 and $71.4 \%$ TDN, respectively). Cows fed BM40 had greater milk yield than DP40, whereas ND40 tended to have greater milk yield and had greater protein and lactose yields compared with DP40. No differences in intake, component-corrected milk yields, or feed efficiency were detected between DP40, BM40, and ND40. Milk yield differences may be due to increased starch intake for ND40 and increased digestible NDF intake for BM40 compared with DP40. Intake and milk yield and composition were similar for ND40 compared with BM40, possibly due to counteracting effects of higher starch intake for ND40 and

Received May 22, 2014.

Accepted August 17, 2014.

${ }^{1}$ Current address: Department of Dairy Science, University of Wisconsin, Madison, WI 53706.

${ }^{2}$ Corresponding author: msakins@wisc.edu
\end{abstract}

higher digestible NDF intake for BM40. Feeding ND65 reduced intake, and thus milk and component yields, compared with ND40 due to either increased ruminal starch digestibility or increased rumen fill for ND65. Nutridense corn silage was a viable alternative to both $\mathrm{DP}$ and $\mathrm{BM}$ at $40 \%$ of diet DM; however, lactation performance was reduced when nutridense corn silage was fed at $65 \%$ of DM.

Key words: corn silage hybrid, brown midrib, nutridense, milk production

\section{INTRODUCTION}

Whole-plant corn silage (WPCS) is the predominant forage in dairy cattle diets in the United States, with the top-ranking states for WPCS and milk production typically corresponding (USDA-NASS, 2013). Traditionally, corn hybrids selected for production of WPCS were conventional or dual-purpose (DP) hybrids with potential for high grain or WPCS yields to allow the grower the option of harvesting the crop as either grain or silage depending on inventory requirements. More recently, however, dairy producers have been selecting corn hybrids for WPCS production based on nutritional quality parameters (Lauer et al., 2013). Corn silage hybrids with the brown midrib (BM) mutation and nutridense (ND) corn have been shown to influence the nutrient content of WPCS and intake, digestion, and lactation performance by dairy cattle. Lignin content is decreased and NDF digestibility increased resulting in greater DMI and milk yield for cows fed BM WPCS compared with conventional hybrids (Oba and Allen, 1999; Ebling and Kung, 2004). Improved NDF digestibility allows for reduced rumen physical fill and thus greater DMI and milk production (Oba and Allen, 2000). The ND corn hybrids were selected for greater protein and oil concentrations in the kernels compared with conventional hybrids (Benefield et al., 2006). Researchers (Akay and Jackson, 2001; Sampson and Spain, 2007) reported improved feed efficiency for lactating cows fed both ND corn grain and silage compared with cows fed both conventional corn grain and silage, whereas feed efficiency was unaffected in the trial of Benefield et al. 
(2006). Chase (2010) reported that lactating cows fed ND WPCS had improved feed efficiency compared with either BM or conventional WPCS in diets containing WPCS (59\% of diet DM) and straw (5.5\% of diet DM) as the only forage sources. Limited comparisons of DP, $\mathrm{ND}$, and BM WPCS have been published. Also, the feeding of corn silage at higher levels is currently being considered due to increased cost for corn grain, greater forage yield per unit area than alfalfa and other forages, and pushes to decrease dietary protein levels to reduce nitrogen excretion. However, there is limited current research on feeding corn silage as the sole forage source. Erdman et al. (2011) showed that cows fed diets with corn silage as the sole forage had similar DMI, milk yield, and protein content but increased milk fat content than cows fed a mixture (50:50) of alfalfa silage and corn silage. An earlier study by Broderick (1985) showed that cows fed diets with corn silage as the sole forage source $(60 \%$ of DM) had similar DMI and milk production but lower milk fat content than cows fed alfalfa silage as the sole forage. Therefore, the primary objective of this study was to determine lactation performance by dairy cows fed DP, ND, or BM WPCS at $40 \%$ of treatment diet DM. In addition, a secondary objective was to determine lactation performance by dairy cows fed ND WPCS as the sole forage $(65 \%$ of diet DM) compared with ND WPCS at $40 \%$ of diet DM.

\section{MATERIALS AND METHODS}

\section{Corn Silage Production}

Corn silage hybrids (DP, Pioneer 34A89, 109 d relative maturity, DuPont Pioneer, Johnston, IA; ND, nutridense 905823, 108 d relative maturity; and BM, Mycogen F2F665, 109 d relative maturity, Mycogen Seeds, Dow AgroSciences LLC, Indianapolis, IN) were planted in a 14-ha field at the University of WisconsinMadison Agricultural Research Station (Arlington, WI) on May 4, 2010, with 76-cm row spacing and 84,000 seeds per hectare. Tillage, fertilizer application, and weed control were the same for the 3 corn silage hybrids, which were in field plots separated by buffer strips planted with a nonexperimental corn grain hybrid. Areas harvested were 4.1, 4.3, and 4.9 ha for DP, ND and BM, respectively. The field plots were harvested as WPCS using a self-propelled forage harvester equipped with a kernel processor (model 6910, John Deere, Moline, IL) set up as follows: 20-cm cutting height, 19-mm theoretical length of cut, and 2-mm roll-gap spacing. Field plots were harvested as soon as possible after kernel maturity progressed to one-half milkline (Bal et al., 1997) on September 7, 13, and 20,
2010, for DP, BM, and ND, respectively. Total metric tonnes of DM harvested and tonnes of $\mathrm{DM} /$ hectare from the respective field plots were 105, 121, and $92 \mathrm{t}$ and 25.6, 28.1, and $19.4 \mathrm{t}$ of $\mathrm{DM} /$ ha for DP, ND, and $\mathrm{BM}$, respectively. The WPCS treatments were stored in separate $3-\mathrm{m} \times 76-\mathrm{m}$ silo bags until the feeding trial commenced on July 7, 2011.

\section{Cows and Treatments}

The animal research was conducted under a protocol approved by the Institutional Animal Care and Use Committee of the College of Agricultural and Life Sciences (University of Wisconsin, Madison). One hundred twenty-eight Holstein (48 multiparous and 64 primiparous) and Holstein $\times$ Jersey (16 multiparous) cows were stratified by breed, parity, and DIM $(105 \pm 38 \mathrm{~d}$ at trial initiation) and randomly assigned to 16 balanced pens of 8 cows each in the University of Wisconsin-Madison sand-bedded freestall barn and milking parlor dairy (Emmons Blaine Dairy Research Center, Arlington, WI). Each pen consisted of 3 Holstein multiparous cows, 4 Holstein primiparous cows, and 1 Holstein $\times$ Jersey multiparous cow. The pens were then randomly assigned to 1 of 4 TMR treatments (4 pens per treatment) with DP, BM, or ND in a completely randomized design continuous-lactation feeding trial.

Three treatments contained $60 \%$ forage DM with two-thirds (40\% of TMR DM) from the respective WPCS (DP40, BM40, and ND40, respectively) and one-third from alfalfa silage. The fourth treatment contained $65 \%$ forage DM entirely from ND corn silage (ND65). The ND65 treatment was included as a comparison to ND40 only. All diets were formulated to be isonitrogenous. Ingredient composition of the experimental diets is in Table 1. A 2-wk covariate period with all pens receiving a TMR containing equal DM proportions of DP40, BM40, and ND40 was followed by an 11-wk treatment period with pens fed their assigned treatment TMR. The TMR were mixed and fed once daily for $5 \%$ feed refusals, with daily DMI measured throughout the study. Daily pen refusals were recorded each morning before new feed delivery using feed management software (Feed Supervisor, Supervisor Systems, Dresser, WI). Daily pen DMI was measured as the difference between as-fed feed offered and as-is feed refused (orts) multiplied by TMR DM content. Nutrient intakes were determined by multiplying the mean DMI of the pen during the study by the nutrient content of the respective treatment TMR.

All cows were injected with bST (Posilac, Elanco Animal Health, Greenfield, IN) every 14 d commencing on $\mathrm{d} 1$ of the covariate period. Body weight and BCS (1 to 5 in 0.25-unit increments; Wildman et al., 1982) were 
Table 1. Ingredient composition (\% of DM) of the experimental diets

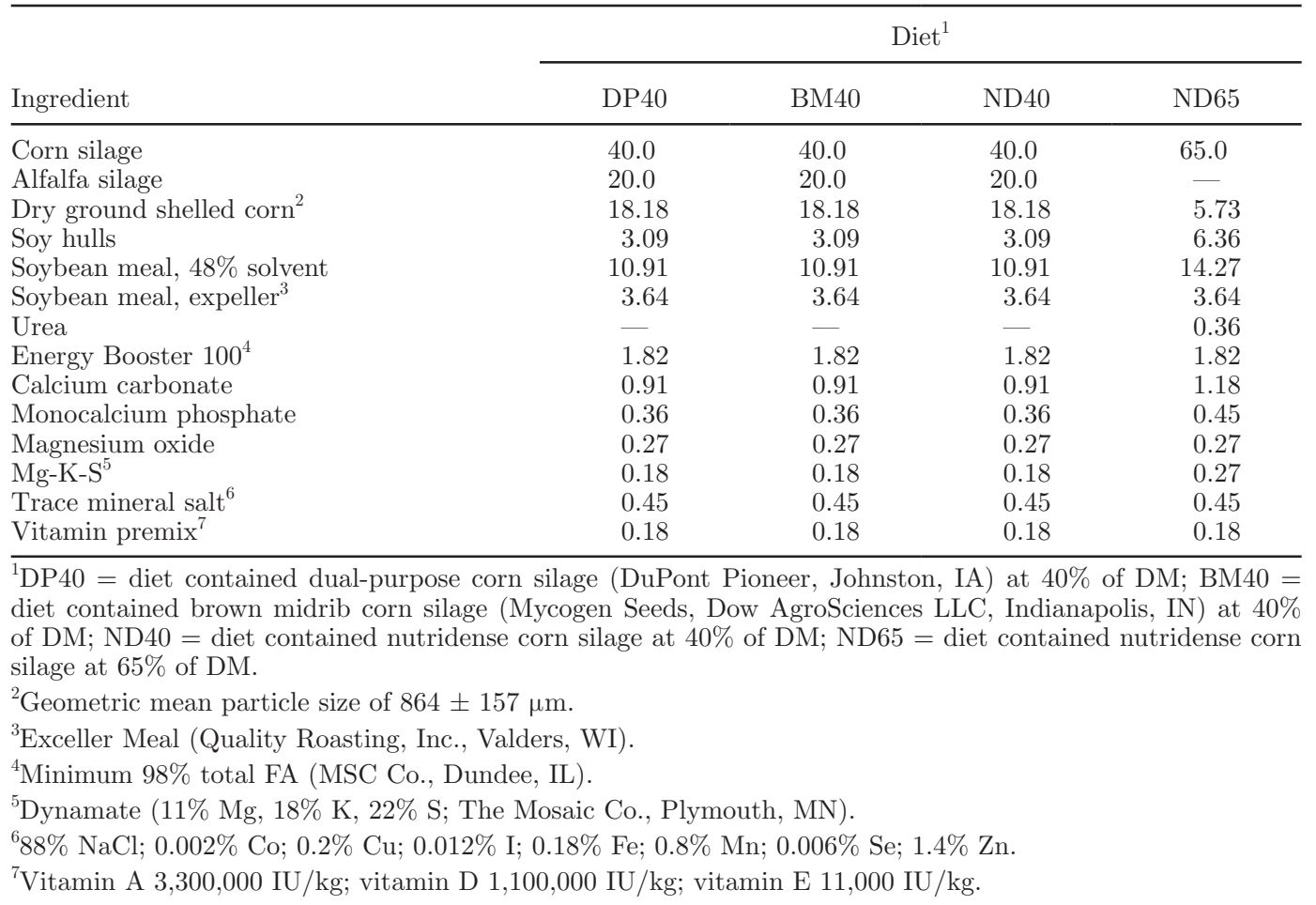

recorded on individual cows at the end of the covariate period and every other week during the treatment period. Body weight change (BWC) was determined by regression of the treatment-period BW measurements over time. Milk yield was recorded daily (DairyComp305, Valley Agricultural Software, Tulare, CA) on individual cows milked twice daily in a double-16 parlor (Metatron P21, GEA Farm Technologies, Bakel, the Netherlands) throughout the trial and composited by pen before statistical analysis. Individual milk samples were obtained every other week from a.m. and p.m. milkings during the treatment period from all cows on the same 2 consecutive days and composited by pen by week. Milk composites were analyzed for fat, true protein, lactose, and MUN concentrations by infrared analysis and SCC by flow cytometry (AgSource Milk Analysis Laboratory, Menomonie, WI) using a CombiFoss $6600 \mathrm{FT}+/ \mathrm{FC}$ (Foss Electric, Hillerød, Denmark) with average daily yields of fat, protein, and lactose calculated from those data for each week. Yields of 3.5\% FCM, SCM, and ECM were calculated according to NRC (2001) equations. Actual milk, 3.5\% FCM, SCM, and ECM feed conversions were calculated by week using average daily yield and DMI data. Estimated diet energy concentration was calculated by summing $\mathrm{NE}_{\mathrm{L}}$ (Mcal) from milk production and that required for maintenance and BW change (NRC, 2001), and then dividing the sum by DMI.
Samples of TMR, WPCS, alfalfa silage, concentrate mixes, and dry ground shelled corn were obtained weekly and then composited for the covariate period and biweekly during the treatment period for analysis. All samples for determination of nutrient composition and ruminal in vitro digestibility were dried at $60^{\circ} \mathrm{C}$ for $48 \mathrm{~h}$ in a forced-air oven to determine DM content, ground to pass a 6-mm Wiley mill (Arthur H. Thomas, Philadelphia, PA) screen, and composited as described before sending to Dairyland Laboratories Inc. (Arcadia, WI) for analysis. At Dairyland Laboratories Inc., all samples were reground to pass a 1-mm Wiley mill (Arthur H. Thomas) screen and analyzed for DM, OM (method 942.05; AOAC International, 2006), CP (method 990.03; AOAC International, 2006), ether extract (EE; method 2003.05; AOAC International, 2006), NDF using $\alpha$-amylase and sodium sulfite (Van Soest et al., 1991), starch (Bach Knudsen, 1997; modified by analyzing glucose using YSI Biochemistry Analyzer; YSI Inc., Yellow Springs, OH). Particle sizes of TMR, corn silage, and alfalfa silage samples were determined as described by Kononoff et al. (2003). Particle size of dry ground shelled corn was determined by dry sieving using Tyler Ro-Tap Shaker (model RX-29, Tyler, Mentor, OH) and sieves with 4,760-, 2,380-, 1,190-, 595-, 297-, 149-, and 63- $\mu \mathrm{m}$ apertures plus bottom pan with mean particle size calculated using a log normal distribution (Baker and Herrman, 2002). 
Ruminal in vitro NDF (NDFD; $30 \mathrm{~h}$ ) digestibility was determined on dried, ground (1-mm screen) WPCS and TMR samples using a modified procedure from Goering and Van Soest (1970), in which the ruminal inoculum contained strained ruminal fluid and blended ruminal solids. Ruminal in vitro starch (STHD; $7 \mathrm{~h}$ ) digestibility was performed on dried, ground (4-mm screen) WPCS, TMR, and corn grain samples using procedures modified from Richards et al. (1995), in which the Goering and Van Soest (1970) method was used, the ruminal inoculum contained strained fluid and blended solids, and the residual starch was analyzed using a modified procedure from Bach Knudsen (1997) with a YSI Biochemistry Analyzer (YSI Inc.). Undried, unground samples of WPCS were analyzed for processing score (Ferreira and Mertens, 2005) and fermentation profile (Muck and Dickerson, 1988).

\section{Statistical Analysis}

Five cows ( 1 cow on BM40, 1 cow on ND40, and 3 cows on ND65) were removed from the study due to mastitis, pneumonia, or displaced abomasum. Data were analyzed as a completely randomized design with the data from the preliminary period as a covariate using PROC MIXED (SAS Institute, 2004), with week of treatment as repeated measures using the first-order autoregressive covariance structure that provided the best fit according to Sawa's Bayesian information criterion. Pen served as the experimental unit for the analysis. The model included treatment, week, and treatment $\times$ week interaction as fixed effects, and pen within treatment as a random effect. Degrees of freedom were calculated using the Kenward-Roger option. Significant treatment $\times$ week interaction effects were partitioned using the SLICE option (SAS Institute, 2004) to determine which weeks had significant treatment differences. Significant differences between DP40, BM40, and ND40 were determined using PDIFF option only after a significant treatment effect. Significant difference between ND40 and ND65 was determined using a contrast statement. Statistical significance and trends were declared at $P \leq$ 0.05 and $0.05<P \leq 0.10$, respectively.

\section{RESULTS AND DISCUSSION}

\section{Corn Silage and TMR Nutrient Analysis}

Results for WPCS nutrient composition, particle size, fermentation profile, and ruminal in vitro digestion parameters are in Table 2. Although harvest of the 3 WPCS treatments commenced as soon as possible after being assessed at the one-half kernel milkline stage of maturity, BM averaged $41.8 \% \mathrm{DM}$ and was 6.6 and 4.5 percentage units drier than $\mathrm{DP}$ and ND, respectively. For the BM, 5 d elapsed between the decision to harvest and the actual harvest with weather conditions favoring a rapid dry-down that resulted in the DM content being greater than desired for the BM WPCS. The concentrations of NDF and starch in WPCS were similar for DP and BM. Ether extract content of ND WPCS (3.8\%) was similar to DP (3.6\%), which differs from results reported by Benefield et al. (2006), where the EE content of ND WPCS was $25 \%$ greater than in WPCS produced from a conventional corn hybrid. Crude protein content of ND WPCS was 0.6 percentage units greater than DP WPCS but similar to that of BM WPCS, which agrees with Chase (2010) and is typical of ND compared with conventional corn hybrids. Benefield et al. (2006) also found ND WPCS to have greater $\mathrm{CP}$ content than conventional corn hybrids; however, Akay and Jackson (2001) reported no difference between ND and conventional corn hybrids harvested as WPCS. The NDF content of ND WPCS was 3.4 percentage units lower and starch content was 4.9 percentage units greater compared with the average for DP and BM. Starch content of ND WPCS in previous studies is variable, with Akay and Jackson (2001) finding greater starch content and Chase (2010) and Benefield et al. (2006) finding lower starch content in ND WPCS compared with conventional hybrid WPCS. Chase (2010) also reported greater NDF content for ND WPCS than for conventional WPCS, which differs from our results. Overall differences in WPCS nutrient composition resulted in a 3.3 percentage unit increase in the $\mathrm{TDN}_{1 \times}$ value calculated for ND using the NRC (2001) summative energy equation compared with the average for DP and BM. Kernel processing score or the percentage of starch that passes through a coarse $(4.75$ $\mathrm{mm}$ ) sieve of $\geq 50$ to $<70 \%$ and $\geq 70 \%$ are considered adequate and optimum, respectively (Mertens, 2005). All 3 WPCS treatments were well processed, with average scores ranging from 68 to $77 \%$. Particle size distributions were similar for the WPCS treatments. The fermentation profiles of the WPCS treatments were similar and indicative of well-preserved silages (Kung and Shaver, 2001).

The NDFD (\% of NDF) was 14.3 percentage units greater for BM than the average of DP and ND, which were similar. Greater ruminal NDFD for BM than DP was expected (Gencoglu et al., 2008). The STHD (\% of starch) appeared similar, with averages ranging from 84 to $89 \%$ across the WPCS treatments. In comparison, the 11,456 corn silage samples analyzed at Dairyland Laboratories Inc. during 2011 (Dairyland Laboratories Inc., 2012) had $81.9 \% \pm 6.3$ STHD (\% of starch). Ammonia-N content, which has been suggested as an indicator of differences in starch digestibility for 
Table 2. Corn silage and alfalfa silage nutrient composition ( \pm SD; \% of DM, unless otherwise noted), particle size $( \pm \mathrm{SD} ; \% \text { as-fed retained), fermentation profile, and ruminal in vitro digestion (means } \pm \mathrm{SD})^{1}$

\begin{tabular}{|c|c|c|c|c|}
\hline Item & DP & BM & ND & Alfalfa silage \\
\hline \multicolumn{5}{|l|}{ Nutrient } \\
\hline DM, $\%$ as fed & $35.2 \pm 1.6$ & $41.8 \pm 1.8$ & $37.3 \pm 1.6$ & $44.1 \pm 2.9$ \\
\hline $\mathrm{OM}$ & $96.0 \pm 0.2$ & $95.6 \pm 0.2$ & $96.0 \pm 0.3$ & $90.9 \pm 0.5$ \\
\hline $\mathrm{CP}$ & $6.6 \pm 0.3$ & $7.1 \pm 0.3$ & $7.2 \pm 0.4$ & $22.2 \pm 1.1$ \\
\hline Ether extract & $3.6 \pm 0.1$ & $3.1 \pm 0.2$ & $3.8 \pm 0.1$ & $3.4 \pm 0.3$ \\
\hline NDF & $42.2 \pm 1.6$ & $42.8 \pm 2.4$ & $39.1 \pm 1.8$ & $37.5 \pm 2.9$ \\
\hline $\mathrm{NFC}$ & $43.9 \pm 1.4$ & $42.9 \pm 2.5$ & $46.3 \pm 2.4$ & $28.0 \pm 1.8$ \\
\hline Starch & $31.9 \pm 1.0$ & $30.4 \pm 2.4$ & $36.0 \pm 1.7$ & $0.8 \pm 0.3$ \\
\hline $\mathrm{TDN}_{1 \times}{ }^{2}$ & $70.7 \pm 0.4$ & $69.5 \pm 1.0$ & $72.4 \pm 0.7$ & $59.2 \pm 1.4$ \\
\hline Starch passing $4.75-\mathrm{mm}$ sieve & $68.3 \pm 5.9$ & $72.1 \pm 6.4$ & $77.1 \pm 4.1$ & - \\
\hline \multicolumn{5}{|c|}{ Penn State Particle Separator sieves } \\
\hline $19 \mathrm{~mm}$ & $2.3 \pm 0.9$ & $2.8 \pm 1.2$ & $2.4 \pm 1.1$ & $11.5 \pm 4.0$ \\
\hline $8 \mathrm{~mm}$ & $68.6 \pm 3.0$ & $58.1 \pm 3.4$ & $64.6 \pm 2.9$ & $66.1 \pm 3.4$ \\
\hline $1.18 \mathrm{~mm}$ & $28.0 \pm 2.9$ & $36.7 \pm 2.5$ & $32.1 \pm 2.4$ & $20.7 \pm 2.7$ \\
\hline Bottom pan & $1.1 \pm 0.5$ & $2.4 \pm 1.0$ & $0.9 \pm 0.4$ & $1.8 \pm 0.6$ \\
\hline \multicolumn{5}{|l|}{ Fermentation profile } \\
\hline $\mathrm{pH}$ & $3.84 \pm 0.10$ & $3.89 \pm 0.19$ & $3.90 \pm 0.05$ & - \\
\hline Lactic acid, \% of DM & $3.5 \pm 0.4$ & $3.8 \pm 0.5$ & $3.0 \pm 0.4$ & - \\
\hline Acetic acid, $\%$ of DM & $1.2 \pm 0.2$ & $0.8 \pm 0.2$ & $1.2 \pm 0.1$ & - \\
\hline Ethanol, \% of DM & $0.6 \pm 0.1$ & $\mathrm{ND}^{3}$ & ND & - \\
\hline Ammonia-N, $\%$ of total $\mathrm{N}$ & $8.0 \pm 1.0$ & $8.3 \pm 0.8$ & $8.7 \pm 0.6$ & - \\
\hline \multicolumn{5}{|l|}{ Ruminal in vitro digestibility } \\
\hline $30-\mathrm{h}$ NDFD, $4 \%$ of NDF & $41.9 \pm 2.8$ & $54.9 \pm 2.6$ & $39.3 \pm 2.2$ & - \\
\hline 7-h STHD, ${ }^{5} \%$ of starch & $88.8 \pm 3.7$ & $84.0 \pm 3.8$ & $85.5 \pm 3.7$ & - \\
\hline
\end{tabular}

ensiled high-moisture corn (Hoffman et al., 2012), was similar across the treatments. The WPCS treatments had been in storage for 10 mo before commencing with the feeding trial and silage sampling over a subsequent 4-mo period, which would likely have attenuated any inherent differences in starch digestibility that may have existed between the WPCS hybrids at harvest (Hoffman et al., 2012).

Results for nutrient composition, particle size, and ruminal in vitro disappearance parameters for TMR treatments are in Table 3. Greater DM content for BM40 than for DP40 and ND40 was related to the WPCS DM content, whereas reduced DM content for ND65 compared with ND40 was related to the increased proportion of corn silage in ND65. Dietary concentrations of forage and total NDF were lower, and NFC and starch concentrations were greater for ND40 than for DP40 and BM40 coincident with the NDF, NFC, and starch concentrations of the WPCS treatments. Furthermore, the dietary $\mathrm{TDN}_{1 \times}$ was greater for ND40 compared with DP40 and BM40, which were similar. The dietary concentration of forage NDF was 2.3 percentage units greater for ND65 than ND40, whereas concentrations of NFC, starch, and $\mathrm{TDN}_{1 \times}$ were similar for these 2 TMR treatments. These nutrient concentra- tions were expected because ND65 contained $65 \%$ corn silage, whereas ND40 contained $40 \%$ corn silage and $20 \%$ alfalfa silage (DM basis). Particle size distributions of the 4 TMR treatments were similar.

The NDFD (\% of NDF) was 10.4 percentage units greater for BM40 than the average of DP40 and ND40 TMR treatments, which were similar, as expected (Gencoglu et al., 2008). The STHD (\% of starch) measurements were similar among the DP40, BM40, and ND40 treatments, whereas that of ND65 was greater than that of ND40. For the ND40 and ND65 TMR treatments, 52 and $85 \%$ of dietary starch, respectively, was provided by the ND WPCS, with an observed STHD of $85.5 \pm 3.7 \%$ of starch. The remainder of the dietary starch in both diets was primarily from dry ground shelled corn with an observed STHD of $74.6 \pm$ $3.8 \%$ of starch. Together, these data can explain the observations of greater STHD for ND65 than ND40 TMR treatments.

\section{Lactation Performance}

Presented in Table 4 are treatment effects on DMI, milk production, feed efficiencies, and BW and BCS covariate-adjusted least squares means. We detected an 
Table 3. Total mixed ration nutrient composition ( $\pm \mathrm{SD} ; \%$ of $\mathrm{DM}$, unless otherwise noted), particle size $( \pm \mathrm{SD} ; \%$ as-fed retained), and ruminal in vitro digestion (means $\pm \mathrm{SD})$

\begin{tabular}{|c|c|c|c|c|}
\hline \multirow[b]{2}{*}{ Item } & \multicolumn{4}{|c|}{ Treatment $^{1}$} \\
\hline & DP40 & BM40 & ND40 & ND65 \\
\hline \multicolumn{5}{|l|}{ Nutrient } \\
\hline DM, $\%$ as fed & $48.3 \pm 1.1$ & $53.2 \pm 1.9$ & $49.9 \pm 0.9$ & $46.5 \pm 1.0$ \\
\hline $\mathrm{OM}$ & $93.0 \pm 0.1$ & $92.8 \pm 0.1$ & $93.0 \pm 0.1$ & $93.2 \pm 0.3$ \\
\hline $\mathrm{CP}$ & $17.0 \pm 0.3$ & $17.0 \pm 0.5$ & $17.1 \pm 0.2$ & $17.0 \pm 0.3$ \\
\hline Ether extract & $5.1 \pm 0.2$ & $5.0 \pm 0.2$ & $5.4 \pm 0.1$ & $5.2 \pm 0.2$ \\
\hline Total NDF & $29.5 \pm 1.3$ & $30.1 \pm 1.1$ & $27.4 \pm 0.8$ & $28.4 \pm 1.5$ \\
\hline Forage NDF & $24.4 \pm 1.2$ & $24.6 \pm 1.5$ & $23.1 \pm 1.3$ & $25.4 \pm 1.2$ \\
\hline NFC & $42.2 \pm 1.1$ & $41.5 \pm 0.7$ & $44.0 \pm 0.7$ & $43.4 \pm 1.4$ \\
\hline Starch & $26.2 \pm 0.8$ & $26.3 \pm 2.1$ & $28.4 \pm 0.9$ & $28.2 \pm 1.4$ \\
\hline $\mathrm{TDN}_{1 \times}^{2}$ & $71.9 \pm 0.7$ & $71.4 \pm 0.5$ & $73.2 \pm 0.4$ & $72.8 \pm 0.6$ \\
\hline \multicolumn{5}{|c|}{ Penn State Particle Separator sieves } \\
\hline $19 \mathrm{~mm}$ & $2.1 \pm 0.8$ & $2.5 \pm 0.9$ & $2.3 \pm 0.8$ & $0.9 \pm 0.3$ \\
\hline $8 \mathrm{~mm}$ & $49.5 \pm 1.2$ & $42.8 \pm 2.2$ & $45.2 \pm 2.1$ & $42.4 \pm 1.7$ \\
\hline $1.18 \mathrm{~mm}$ & $37.6 \pm 1.6$ & $41.8 \pm 2.4$ & $40.9 \pm 1.7$ & $47.4 \pm 2.2$ \\
\hline Bottom pan & $10.9 \pm 0.9$ & $12.8 \pm 0.4$ & $11.6 \pm 1.0$ & $9.4 \pm 0.9$ \\
\hline \multicolumn{5}{|l|}{ Ruminal in vitro } \\
\hline $30-\mathrm{h}$ NDFD, ${ }^{3} \%$ of NDF & $49.3 \pm 2.4$ & $58.9 \pm 2.6$ & $47.7 \pm 2.5$ & $49.3 \pm 2.5$ \\
\hline 7 -h STHD, ${ }^{4} \%$ of starch & $77.0 \pm 2.8$ & $79.5 \pm 5.0$ & $80.0 \pm 1.9$ & $82.7 \pm 4.8$ \\
\hline \multicolumn{5}{|c|}{$\begin{array}{l}{ }^{1} \text { DP } 40=\text { diet contained dual-purpose corn silage (DuPont Pioneer, Johnston, IA) at } 40 \% \text { of DM; BM40 } \\
\text { diet contained brown midrib corn silage (Mycogen Seeds, Dow AgroSciences LLC, Indianapolis, IN) at } 40 \% \\
\text { DM; ND } 40=\text { diet contained nutridense corn silage } 40 \% \text { of DM; ND65 = diet contained nutridense corn sila } \\
\text { at } 65 \% \text { of DM. }\end{array}$} \\
\hline
\end{tabular}

interaction of treatment and time $(P<0.01)$ for DMI (Figure 1), with ND65 having lower DMI than the other treatments in 5 of the $11 \mathrm{wk}$, with no pattern to these differences. Differences among the other 3 treatments were variable across the study and we have no explanation for the observed DMI changes over time. Also, we found interactions of treatment and time for feed efficiency (Figure 2; $P=0.05$ ) and milk protein percentage (Figure 3; $P=0.05$ ), with treatments varying during the study with no definite trends and no treatment differences were found within week when interactions were partitioned by week. Milk protein percentage did increase over time for all treatments from 2.9 to $3.2 \%$ protein with minimal differences between treatments.

Milk yield was greater for BM40 than DP40 (40.7 vs. $38.8 \mathrm{~kg} / \mathrm{d}, P=0.02)$, tended to be greater for ND40 than DP40 (40.2 vs. $38.8 \mathrm{~kg} / \mathrm{d} ; P=0.09)$, and was similar $(P>0.10)$ for ND40 compared with BM40. Component-adjusted milk yields were similar across DP40, BM40, and ND40 $(P>0.10)$. Although DMI (average of $24.3 \mathrm{~kg} / \mathrm{d})$ was similar $(P>0.10)$ across these 3 treatments, ND40 had greater $(P<0.01)$ intakes of fat, NFC, starch, and rumen digestible starch than DP40, whereas BM40 had greater intakes of rumen digestible NDF $(P<0.01)$ than DP40 (Table 5). Increased intake of these nutrients may explain the milk yield differences due to greater available energy for BM40 and ND40 compared with DP40. Sampson and Spain (2007) observed decreased DMI when feeding diets with either ND corn grain replacing conventional corn grain only or ND corn grain and WPCS replacing both conventional corn grain and WPCS; however, milk yield was unaffected. Benefield et al. (2006) and Akay and Jackson (2001) reported no differences in DMI or milk yield for cows fed ND WPCS compared with WPCS produced from conventional corn hybrids.

The lack of DMI response for BM40 with its greater corn silage and TMR 30-h in vitro NDFD compared with DP40 and ND40 (Tables 2 and 3) was unexpected (Gencoglu et al., 2008) but may have been related to the trial being performed on mid-lactation cows between 100 and 200 DIM where rumen fill may not be limiting energy intake relative to production requirements (Mertens, 1987; Allen, 2000). These results differ from those of Chase (2010), who reported increased DMI for early lactation (study commenced at 7 to 12 d of lactation) cows fed BM WPCS compared with DP and ND WPCS, with WPCS making up 59\% of diet DM. Holt et al. (2013) found no difference in milk yield and DMI from parturition to peak lactation (1-60 DIM), but BW loss was less for cows fed BM WPCS compared with conventional WPCS. After peak lactation, DMI and milk yield were greater for cows fed BM WPCS (Holt et al., 2013). Other comparisons between 
Table 4. Treatment effects on covariate-adjusted least squares means for intake, milk production, feed efficiencies, BW, and BCS

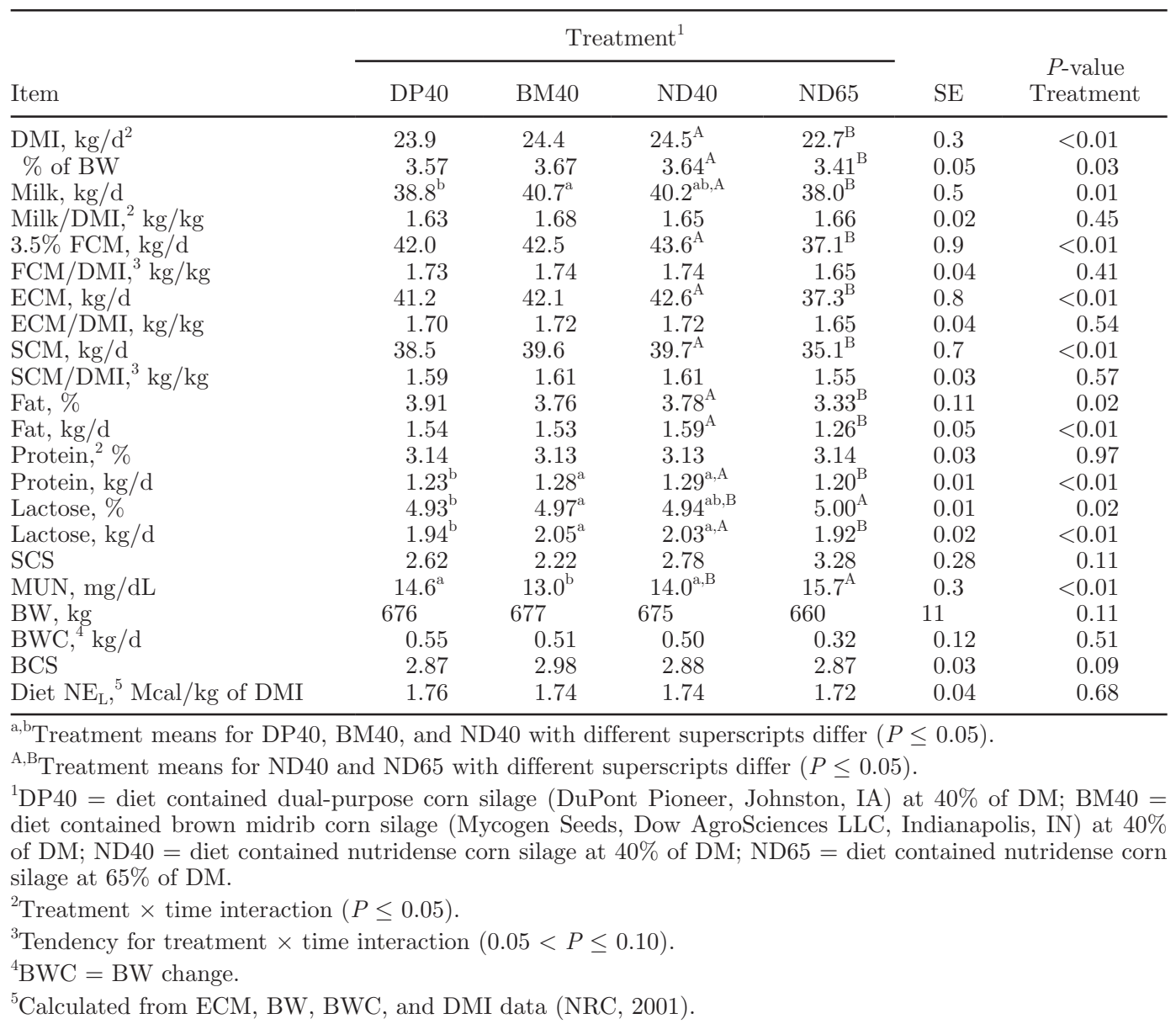

BM and conventional WPCS have been variable, with some finding increased lactation performance with BM WPCS (Oba and Allen, 1999; Ebling and Kung, 2004) and others finding no difference (Bal et al., 2000; Taylor and Allen, 2005). Gencoglu et al. (2008) reviewed 11 studies published from 1999 to 2008 and found increases of $1.2 \mathrm{~kg}$ of DMI and $1.7 \mathrm{~kg}$ of milk for cows fed BM WPCS versus conventional WPCS. Total and forage NDF intakes across the 4 treatments were less than or equal to 1.11 and $0.90 \%$ of BW (Table 5), respectively, and not considered to be fill limiting (Mertens, 1987). Counteracting effects (Table 5 ) of greater rumen digestible starch intake for ND40 over BM40 $(P<0.01)$ but greater rumen digestible NDF intake for BM40 over ND40 $(P<0.01)$ may explain the lack of production differences $(P>0.01)$ between these 2 treatments.

No differences $(P>0.10)$ in milk fat percentage and yield were observed between DP40, BM40, and ND40. Milk protein concentrations were not different $(P>$ 0.10) between DP40, BM40, and ND40; however, protein yield was greater $(P \leq 0.03)$ for BM40 and ND40 compared with DP40. Cows fed BM40 and ND40 had greater digestible starch intakes $(P<0.01)$ than DP40, which may have increased ruminal microbial protein synthesis and milk protein synthesis (NRC, 2001). Akay and Jackson (2001) observed a tendency for lower milk protein content for cows fed diets containing ND WPCS that was attributed to ND corn hybrids having higher oil content, which can reduce milk protein percentage (Weiss and Wyatt, 2000), but no difference in protein yield was observed. In the current study, cows fed ND40 had greater $(P<0.01)$ EE intake than DP40 and BM40, with no differences in milk protein percentage.

All measures of feed efficiency were similar $(P>0.10)$ between DP40, BM40, and ND40. This contrasts previous studies that found improved feed efficiency of cows fed diets with ND WPCS compared with conventional (Akay and Jackson, 2001; Sampson and Spain, 2007) or both conventional and BM WPCS (Chase, 2010). Benefield et al. (2006), however, found no improvement in feed efficiency when feeding ND WPCS compared 


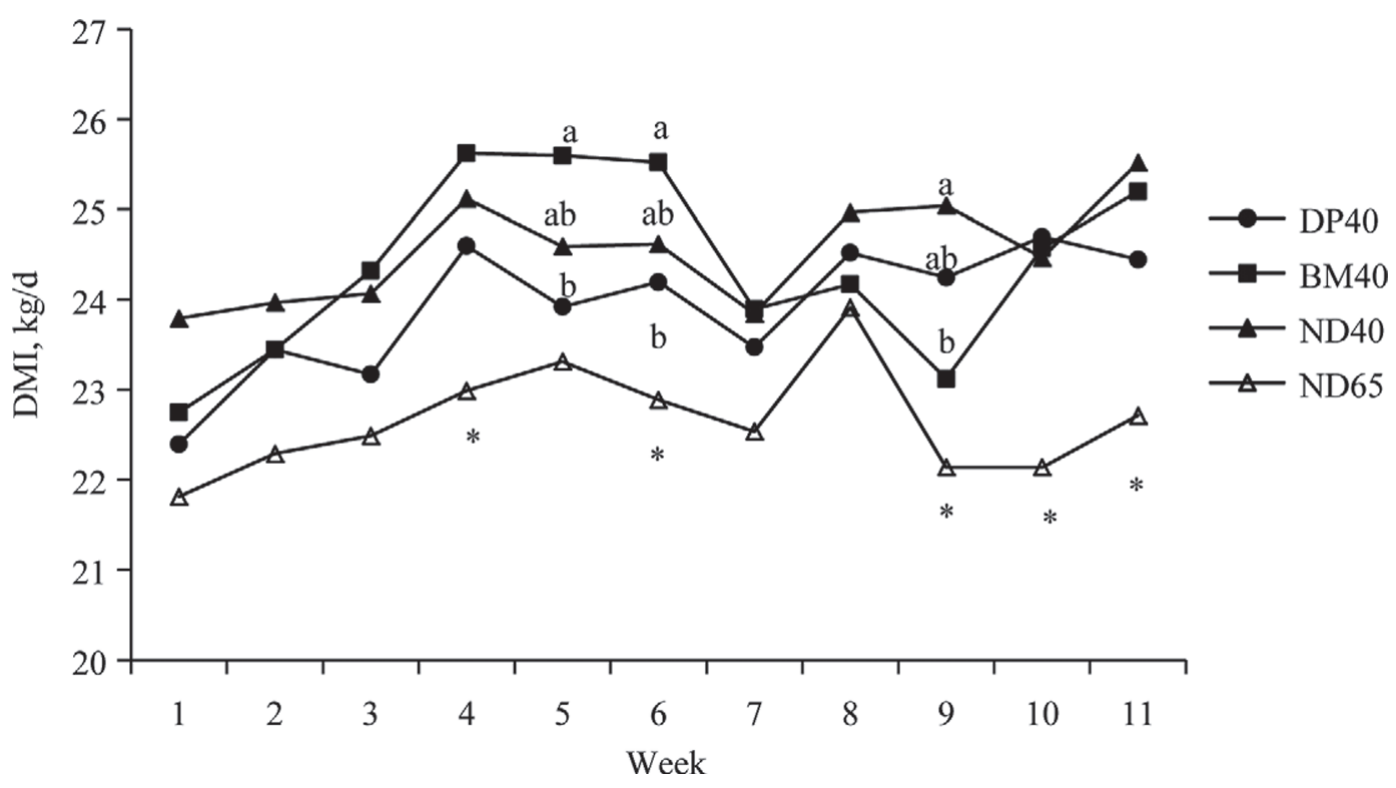

Figure 1. Treatment effects on covariate-adjusted least squares means for DMI over time. The DP40 diet contained dual-purpose corn silage (DuPont Pioneer, Johnston, IA) at 40\% of DM; BM40 diet contained brown midrib corn silage (Mycogen Seeds, Dow AgroSciences LLC, Indianapolis, IN) at $40 \%$ of DM; ND40 diet contained nutridense corn silage at $40 \%$ of DM; ND65 diet contained nutridense corn silage at $65 \%$ of DM. Treatment by week interaction $(P<0.01)$. SEM $=0.47$. ${ }^{\mathrm{a}, \mathrm{b}}$ Least squares means for DP40, BM40, and ND40 within week with different letters differ $(P<0.05)$; *least squares means for ND40 and ND65 within week differ $(P<0.05)$.

with a conventional corn hybrid similar to the results of the current study.

Milk urea-N was greater for DP40 and ND40 compared with BM40 $(P<0.05)$. Previous research has reported increased ruminal $\mathrm{NH}_{3}$ (Akay and Jackson, 2001; Benefield et al., 2006; Sampson and Spain, 2007) and MUN concentrations (Benefield et al., 2006) for ND treatments due to increased RDP in ND corn. Body weight $(P=0.11)$ and BWC were unaffected $(P$ $=0.93)$ by treatment.

Dry matter intake and milk yield were reduced by 1.8 $(P<0.01)$ and $2.2(P=0.02) \mathrm{kg} / \mathrm{d}$, respectively, for ND65 compared with ND40. Furthermore, milk fat content and yield were reduced by 0.45 percentage units $(P=0.01)$ and $0.33 \mathrm{~kg} / \mathrm{d}(P<0.01)$, respectively, for ND65 compared with ND40. Reduced DMI and intakes of OM, CP, fat, NFC, and starch $(P<0.01$; Table 5) and consequently milk yield along with reduced milk fat could be related to greater ruminal starch digestion (Allen, 1997; Allen et al., 2009) for ND65 compared with ND40. As discussed previously, of the total dietary starch, 52\% for ND40 and 85\% for ND65 was provided by WPCS with greater ruminal digestibility than the dry ground shelled corn, which comprised most of the remainder of dietary starch. An alternative explanation for reduced DMI by cows fed ND65 could be a rumenfill limitation of DMI because dietary forage NDF content was 2.3 percentage units greater for ND65 than for ND40 (Table 3). However, this explanation seems less likely than the one discussed for ruminal starch digestibility, because total and forage NDF intakes for ND65 were 0.97 and $0.87 \%$ of $\mathrm{BW}$ (Table 5), respectively, which would not be considered fill limiting (Mertens,

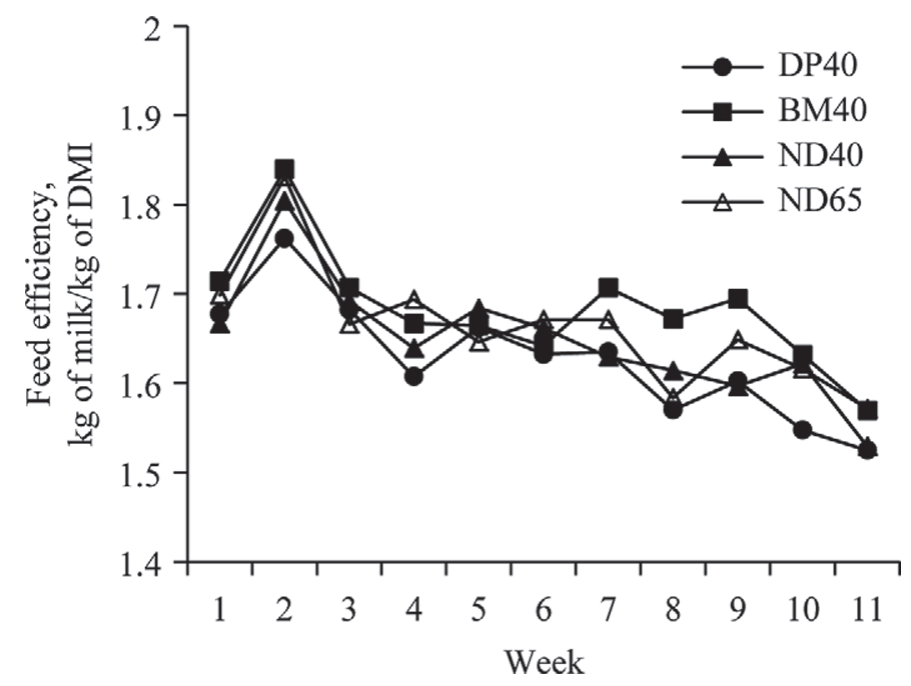

Figure 2. Treatment effects on covariate-adjusted least squares means for feed efficiency ( $\mathrm{kg}$ of milk/ $\mathrm{kg}$ of DMI) over time. The DP40 diet contained dual-purpose corn silage (DuPont Pioneer, Johnston, IA) at $40 \%$ of DM; BM40 diet contained brown midrib corn silage (Mycogen Seeds, Dow AgroSciences LLC, Indianapolis, IN) at $40 \%$ of DM; ND40 diet contained nutridense corn silage at $40 \%$ of DM; ND65 diet contained nutridense corn silage at $65 \%$ of DM. Treatment by week interaction $(P=0.05)$. SEM $=0.031$. 
Table 5. Treatment effects on covariate-adjusted least squares means for nutrient intakes

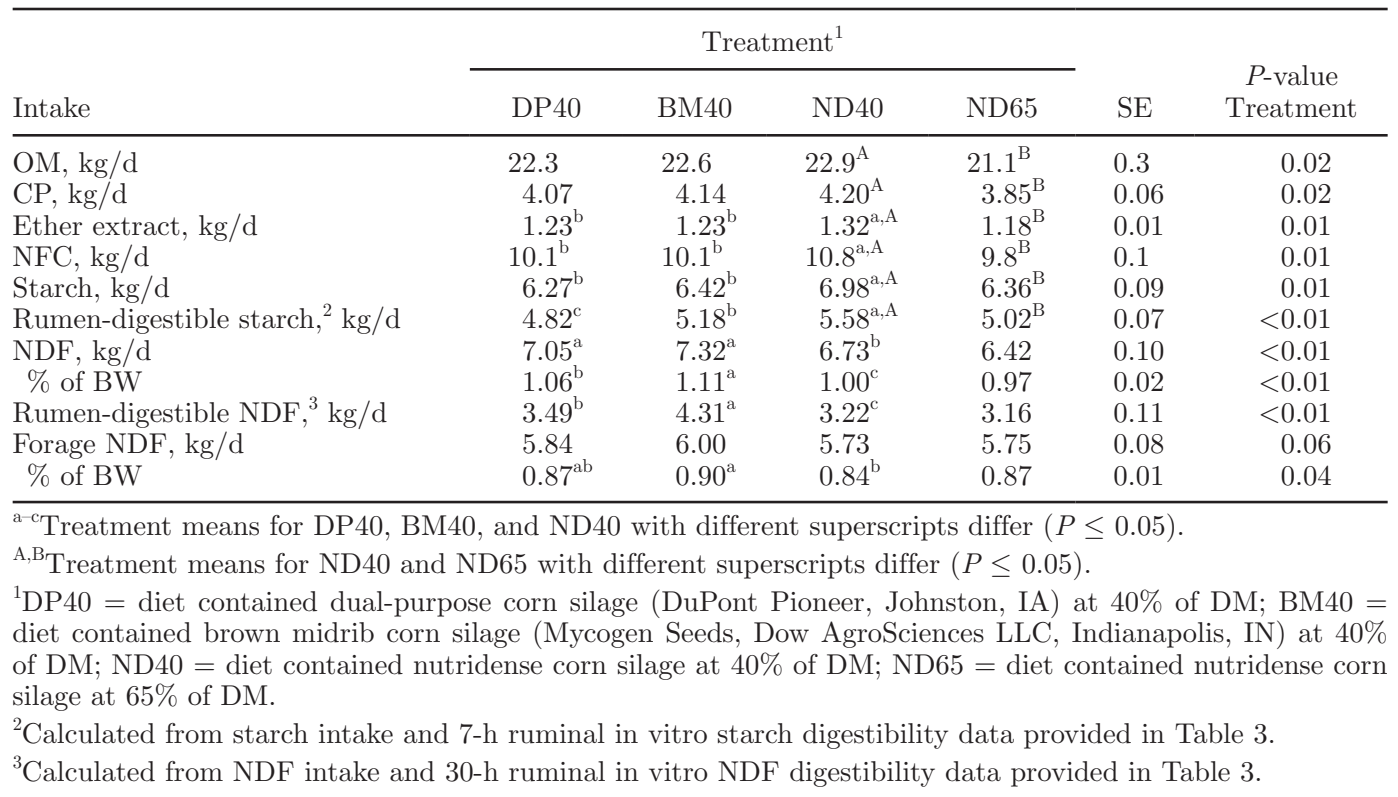

1987). Coincident with the milk yield differences, yields of protein $(P<0.01)$ and lactose $(P=0.01)$ were reduced for ND65 compared with ND40. The resultant calculated yields of $3.5 \%$ FCM, ECM, and SCM were also reduced $(P<0.01)$ for ND65 compared with ND40. The MUN concentration was $12 \%$ greater $(P$ $<0.01)$ for ND65 than for ND40. This response may

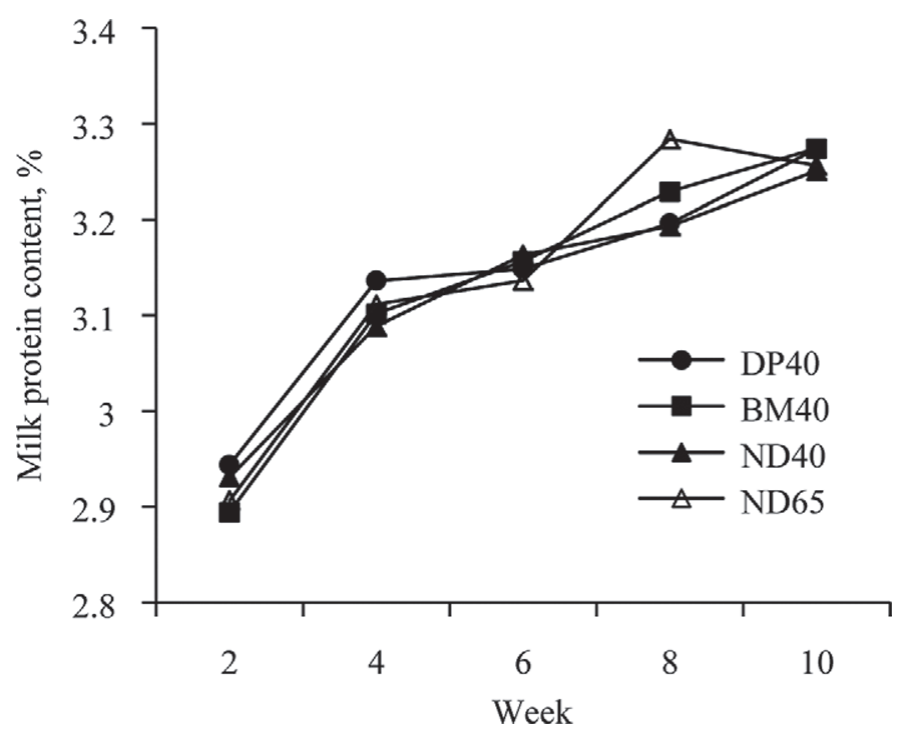

Figure 3. Treatment effects on covariate-adjusted least squares means for milk protein content (\%) over time. The DP40 diet contained dual-purpose corn silage (DuPont Pioneer, Johnston, IA) at $40 \%$ of DM; BM40 diet contained brown midrib corn silage (Mycogen Seeds, Dow AgroSciences LLC, Indianapolis, IN) at 40\% of DM; ND40 diet contained nutridense corn silage at $40 \%$ of DM; ND65 diet contained nutridense corn silage at $65 \%$ of DM. Treatment by week interaction $(P=0.05)$. SEM $=0.031$. have been related to reduced ruminal $\mathrm{pH}$ from greater starch digestibility, as suggested by milk fat depression, thereby reducing the efficiency of using ammonia for rumen microbial protein synthesis (Russell et al., 1992). Also, increased MUN for ND65 may be related to higher degradable protein in ND65 due to a higher level of well-fermented (10 mo) corn silage that has the zein protein matrix of the corn grain degraded over time (Hoffman et al., 2011). Body weight and BWC were unaffected by treatments ND40 and ND65.

\section{CONCLUSIONS}

Different corn silage hybrids fed at $40 \%$ of diet DM influenced milk yield, with cows fed BM having greater and ND tending to have greater milk yield than DP. Milk protein and lactose yields were greater for ND and BM compared with DP WPCS fed at $40 \%$ of diet DM. However, component-corrected milk yields were similar across hybrids. Intake was not affected by corn silage hybrid when fed at $40 \%$ of diet DM; however, when ND was fed as the sole forage source at $65 \%$ of diet DM, cows had lower DMI, which resulted in lower milk and component yields. Additional research on diets with corn silage as the sole forage is needed to determine effects of using other hybrids (DP and BM), harvest management (particle size and processing), and differences in kernel endosperm properties on lactation performance. Overall, cows fed BM and ND WPCS had improved lactation performance compared with DP WPCS, but decisions on corn silage hybrid should also consider agronomic aspects, including yield potential. 


\section{REFERENCES}

Akay, V., and J. A. Jackson Jr.. 2001. Effects of NutriDense and waxy corn hybrids on the rumen fermentation, digestibility, and lactational performance of dairy cows. J. Dairy Sci. 84:1698-1706.

Allen, M. S. 1997. Relationship between fermentation acid production in the rumen and the requirement for physically effective fiber. J. Dairy Sci. 80:1447-1462.

Allen, M. S. 2000. Effects of diet on short-term regulation of feed intake by lactating dairy cattle. J. Dairy Sci. 83:1598-1624.

Allen, M. S., B. J. Bradford, and M. Oba. 2009. The hepatic oxidation theory of the control of feed intake and its application to ruminants. J. Anim. Sci. 87:3317-3334.

AOAC International. 2006. Official Methods of Analysis. 18th ed. AOAC International, Arlington, VA.

Bach Knudsen, K. E. 1997. Carbohydrate and lignin contents of plant materials used in animal feeding. Anim. Feed Sci. Technol. 67:319-338.

Baker, S., and T. Herrman. 2002. Evaluating particle size. MF-2051. Kansas State Univ. Coop. Ext. Serv. Manhattan, KS.

Bal, M. A., J. G. Coors, and R. D. Shaver. 1997. Impact of the maturity of corn for use as silage in the diets of dairy cows on intake, digestion, and milk production. J. Dairy Sci. 80:2497-2503.

Bal, M. A., R. D. Shaver, H. Al-Jobeile, J. G. Coors, and J. G. Lauer 2000. Corn silage hybrid effects on intake, digestion, and milk production by dairy cows. J. Dairy Sci. 83:2849-2858.

Benefield, B. C., M. Lineiro, I. R. Ipharraguerre, and J. H. Clark. 2006. NutriDense corn grain and corn silage for dairy cows. J Dairy Sci. 89:1571-1579.

Broderick, G. A. 1985. Alfalfa silage or hay versus corn silage as the sole forage for lactating dairy cows. J. Dairy Sci. 68:3262-3271.

Chase, L. E. 2010. Milk production and feed efficiency in dairy cows fed corn silage hybrids varying in fiber digestibility. J. Dairy Sci. 93(Suppl. 1):755. (Abstr.)

Dairyland Laboratories Inc. 2012. Forage Summaries 2011. Accessed Jun. 1, 2012. http://www.dairylandlabs.com/pages/interpretations/ forage_2011.php.

Ebling, T. L., and L. Kung Jr.. 2004. A comparison of processed conventional corn silage to unprocessed and processed brown midrib corn silage on intake, digestion, and milk production by dairy cows. J. Dairy Sci. 87:2519-2526.

Erdman, R. A., L. S. Piperova, and R. A. Kohn. 2011. Corn silage versus corn silage:alfalfa hay mixtures for dairy cows: Effects of dietary potassium, calcium, and cation-anion difference. J. Dairy Sci. 94:5105-5110.

Ferreira, G., and D. R. Mertens. 2005. Chemical and physical characteristics of corn silages and their effects on in vitro disappearance. J. Dairy Sci. 88:4414-4425.

Gencoglu, H., R. Shaver, and J. Lauer. 2008. Brown midrib corn silage for lactating dairy cows: A contemporary review. Accessed Jun. 1 , 2012. www.uwex.edu/ces/dairynutrition/ documents/BMRfeeding trialreview2008web.pdf.

Goering, H. K., and P. J. Van Soest. 1970. Forage Fiber Analysis: Apparatus, Reagents, Procedures and Some Applications. Agric. Handbook. 379. Agricultural Research Service, USDA, Washington, DC.

Hoffman, P. C., N. M. Esser, R. D. Shaver, W. Coblentz, M. P. Scott, A. L. Bodnar, R. Schmidt, and B. Charley. 2011. Influence of ensiling time and inoculation on alteration of the starch-protein matrix in high-moisture corn. J. Dairy Sci. 94:2465-2474.

Hoffman, P. C., D. R. Mertens, J. Larson, W. K. Coblentz, and R. D. Shaver. 2012. A query for effective mean particle size in dry and high-moisture corns. J. Dairy Sci. 95:3467-3477.
Holt, M. S., K. Neal, J.-S. Eun, A. J. Young, J. O. Hall, and K. E. Nestor. 2013. Corn silage hybrid type and quality of alfalfa hay affect dietary nitrogen utilization by early lactating dairy cows. J. Dairy Sci. 96:6564-6576.

Kononoff, P. J., A. J. Heinrichs, and D. R. Buckmaster. 2003. Modification of the Penn State forage and total mixed ration particle separator and the effects of moisture content on its measurements. J. Dairy Sci. 86:1858-1863.

Kung, L., and R. Shaver. 2001. Interpretation and use of silage fermentation analysis reports. In Focus on Forage Vol. 3: No. 13 University of Wisconsin Ext. Team Forage. Accessed Jun. 1, 2012. http://www.uwex.edu/ces/crops/uwforage/Fermentaion.html.

Lauer, J., K. Kohn, and T. Diallo. 2013. Wisconsin corn hybrid performance trials: Grain - Silage - Specialty - Organic. UWEX. A3653 Madison, WI. Accessed Jan. 20, 2014. http://corn.agronomy.wisc. edu/HT/2013/2013Text.aspx.

Mertens, D. R. 1987. Predicting intake and digestibility using mathematical models of ruminal function. J. Anim. Sci. 64:1548-1558.

Mertens, D. R. 2005. Particle size, fragmentation index, and effective fiber: Tools for evaluating the physical attributes of corn silages. Page 211 in Proc. Four-State Dairy Nutr. Mgmt. Conf. MWPS4SD18. Dubuque, IA. MidWest Plan Service, Ames, IA.

Muck, R. E., and J. T. Dickerson. 1988. Storage temperature effects on proteolysis in alfalfa silage. Trans. ASAE 31:1005-1009.

NRC. 2001. Nutrient Requirements of Dairy Cattle. 7th rev. ed. Natl Acad. Press, Washington, DC.

Oba, M., and M. S. Allen. 1999. Effects of brown midrib 3 mutation in corn silage on dry matter intake and productivity of high-yielding dairy cows. J. Dairy Sci. 82:135-142.

Oba, M., and M. S. Allen. 2000. Effects of brown midrib 3 mutation in corn silage on productivity of dairy cows fed two concentrations of dietary neutral detergent fiber: 1 . Feeding behavior and nutrient utilization. J. Dairy Sci. 83:1333-1341.

Richards, C. J., J. F. Pedersen, R. A. Britton, R. A. Stock, and C. R. Krehbiel. 1995. In vitro starch disappearance procedure modifications. Anim. Feed Sci. Technol. 55:35-45.

Russell, J. B., J. D. O'Connor, D. G. Fox, P. J. Van Soest, and C. J. Sniffen. 1992. A net carbohydrate and protein system for evaluating cattle diets: I. Ruminal fermentation. J. Anim. Sci. 70:35513561.

Sampson, J., and J. Spain. 2007. Use of NutriDense corn variety for corn and corn silage in diets fed to high producing dairy cows. J. Dairy Sci. 90(Suppl. 1):556. (Abstr.)

SAS Institute. 2004. SAS/STAT 9.1 User's Guide. Version 9.1 ed. SAS Institute Inc., Cary, NC.

Taylor, C. C., and M. S. Allen. 2005. Corn grain endosperm type and brown midrib 3 corn silage: Feeding behavior and milk yield of lactating cows. J. Dairy Sci. 88:1425-1433.

USDA-NASS. 2013. Agricultural statistics 2013. Accessed Jan. 20 , 2014. www.nass.usda.gov/Publications/Ag_Statistics/2013/index. asp.

Van Soest, P. J., J. B. Robertson, and B. A. Lewis. 1991. Methods for dietary fiber, neutral detergent fiber, and nonstarch polysaccharides in relation to animal nutrition. J. Dairy Sci. 74:3583-3597.

Weiss, W. P., and D. J. Wyatt. 2000. Effect of oil content and kernel processing of corn silage on digestibility and milk production by dairy cows. J. Dairy Sci. 83:351-358

Wildman, E. E., G. M. Jones, P. E. Wagner, R. L. Boman, H. F. Troutt, and T. N. Lesch. 1982. A dairy cow body condition scoring system and its relationship to selected production characteristics. J. Dairy Sci. 65:495-501. 